\title{
Acute and Subchronic Oral Toxicity Assessment of the Ethanolic Extract of the root of Oncoba spinosa (Flacourtiaceae) in Rodents
}

\author{
Kumar M Prasanth ${ }^{1 \star}$, V Suba ${ }^{2}$, B Ramireddy ${ }^{3}$, Babu P Srinivasa ${ }^{4}$ \\ ${ }^{1}$ Faculty of Pharmaceutical Sciences, Jawaharlal Nehru Technological University, Hyderabad, Telangana, ${ }^{2}$ Department of \\ Pharmacology, National Institute of Siddha, Tambaram Sanatorium, Chennai, ${ }^{3}$ NATCO Pharma, Hyderabad, Telangana, \\ ${ }^{4}$ Vignan Pharmacy College, Vadlamudi, Guntur, Andhrapradesh, India
}

${ }^{*}$ For correspondence: Email: prasanth.pharmacology@gmail.com

\begin{abstract}
Purpose: To investigate the toxicological profile of the ethanol extract of Oncoba spinosa (EEOS) after acute and sub-chronic administration to rodents.

Methods: In the acute toxicity study, a single administration of the extract at doses of 2000 and 5000 $\mathrm{mg} / \mathrm{kg}$, respectively, was given to the mice. Mice were observed for general behavioural changes, adverse effects and mortality up to 14 days post-treatment. In sub-acute toxicity studies, EEOS was given orally to male and female rats at doses of $250 \mathrm{mg} / \mathrm{kg}, 500 \mathrm{mg} / \mathrm{kg}$ and $1000 \mathrm{mg} / \mathrm{kg}$ for 28 days. Body weight, food intake and water intake were monitored throughout the experimental period; hematological parameters, biochemical parameters of the blood and histopathology of various organs were also evaluated at the end of the experiment.

Results: In the acute toxicity study, both the doses used did not cause any mortality or significant behavioural changes. Daily oral administration of EEOS for 28 days, in the sub-chronic toxicity study, did not show any treatment-related abnormalities with regard to hematological and biochemical parameters. There were no significant differences in body weight and organ weight between the control and treated groups $(p<0.05)$. Histological analysis did not show any morphological changes in the major vital organs (liver, kidney, stomach, spleen, brain and heart) tested.

Conclusion: These results demonstrate that the extract may not have any single dose toxicity. The LD50 value is greater than $5000 \mathrm{mg} / \mathrm{kg}$. The no-observed adverse effects level (NOAEL) was considered to be $1000 \mathrm{mg} / \mathrm{kg}$ for male and female rats, respectively.
\end{abstract}

Keywords: Oncoba spinosa, Acute and sub-acute toxicity, Hematological, Biochemical parameters

Tropical Journal of Pharmaceutical Research is indexed by Science Citation Index (SciSearch), Scopus, International Pharmaceutical Abstract, Chemical Abstracts, Embase, Index Copernicus, EBSCO, African Index Medicus, JournalSeek, Journal Citation Reports/Science Edition, Directory of Open Access Journals (DOAJ), African Journal Online, Bioline International, Open-J-Gate and Pharmacy Abstracts

\section{INTRODUCTION}

Medicinal plants constitute an important part of the health care system for the prevention and treatment of various disorders, since the ancient civilization. Previous studies have shown that 30 $\%$ of the marketed drugs contain active principles that were isolated for the first time from plants [1]. Herbal preparations prepared from medicinal plants can bring about a solution to certain disorders, mostly in developing countries where the commercial drugs are expensive and not easily available to the poor people [2]. In fact, there is lack of evidence on quality, safety and efficacy of many herbal preparations. Although many herbal preparations are non-toxic, many plants currently used for medicines have been shown to be highly toxic when given either 
acutely or sub-chronically [3,4]. The increasing number of plant based medication users around the globe and lack of experimental reports on their safety make it basic to direct toxicological investigation on natural herbal products [5]. In this respect, an earlier study revealed severe hepatotoxicity with the utilization of some herbal plants [6].

The concern for herbal toxicity has raised anxiety among different national and international regulatory authorities to figure and execute different guidelines for surveying, monitoring and preventing toxicity emerging due to herbal products. For example, Uppsala Monitoring Centre in WHO collates and distributes data with respect to unfavourable responses of herbal products whereas Organization for Economic Cooperation and Development (OECD) sets various guidelines and procedures for conducting toxicity studies. Many herbal products in the market are frequently identified with toxic effects.

Oncoba spinosa, the snuff-box tree, fried egg tree or fried-egg flower, is a spiny shrub that belongs to family of Flacourtiaceae which has about 95 genera and 800-1000 species. The leaves are dark, glossy green in colour and somewhat leathery and hairless. The fruits are grown up to $60 \mathrm{~mm}$ in diameter and consists of hard shell that becomes dark-reddish brown when mature with shiny seeds embedded in a dry yellowish pulp [7]. To the best of our knowledge, no reports were available on the safety profile of this plant despite its traditional use in the treatment of diabetes, tumour, dysentery and bladder complaints [8].

As a part of safety evaluation, acute and sub acute oral dose toxicity studies were carried out to investigate the potential toxicity after single oral dosing of extract in mice and 28-day repeated oral dosing of extract in rats.

\section{EXPERIMENTAL}

\section{Collection and identification of plant materials}

Fresh roots of Oncoba spinosa were collected from Tirupathi, Andhrapradesh. The plant was identified and authenticated taxonomically by $\mathrm{Dr}$ K Madhava Chetty of the Department of Botany, S.V. University, Tirupathi, AndhraPradesh, India. A voucher specimen of the collected sample was deposited in the herbarium of the institution for future reference.

\section{Preparation of the extract}

The roots were shade dried and made into coarse powder and extracted with $70 \%$ ethanol by cold maceration method for $72 \mathrm{~h}$ with intermittent shaking. The extract was filtered and concentrated at high vacuum and then stored in the refrigerator till used.

\section{Animals}

Swiss albino mice (25-30 g) were selected for acute toxicity studies and Wistar albino rats of both sexes and weighing 130 - $200 \mathrm{~g}$ were selected for sub-acute toxicity studies. The animals had free access to food and water and were maintained under standard laboratory conditions which included 12-hour light-dark cycle and temperature of $28-30{ }^{\circ} \mathrm{C}$. Animals were allowed a one-week acclimatization period prior to the study. The experimental protocol was approved by the Animal Ethical Committee of the Jawaharlal Nehru Technological University, Hyderabad, Telangana.

\section{Acute toxicity studies}

Acute toxicity studies of ethanolic extract of Oncoba spinosa (EEOS) was carried out in female mice by using Organisation for Economic Co-operation and Development (OECD) guideline 425 [9]. Before oral administration of a single dose of the test samples, the mice were deprived of food for $3 \mathrm{~h}$. Doses of 2000 and 5000 $\mathrm{mg} / \mathrm{kg}$ of the test samples were given using oral gavage to mice of Group I and Group II respectively. All the mice were observed for general behavioral changes; symptoms of toxicity and mortality after treatment for the first four (critical) hours, then over a period of $24 \mathrm{~h}$, thereafter daily for 14 days.

\section{Sub-acute toxicity studies}

Sub-acute toxicity study (28-day repeated oral toxicity study) was carried out according to OECD 407 guidelines [10]. Both sexes of rats $(130-200 \mathrm{~g})$ were divided into four groups with 10 animals ( 5 males plus 5 females in each). The group I received $1 \%$ carboxylmethylcellulose (CMC) vehicle orally at a dose of $10 \mathrm{ml} / \mathrm{kg}$ body weight and served as a control group whereas the rats in groups II, III and IV were treated with EEOS at the doses of $250 \mathrm{mg} / \mathrm{kg}, 500 \mathrm{mg} / \mathrm{kg}$ and $1000 \mathrm{mg} / \mathrm{kg}$ body weight continuously up to 28 days by suspending in $1 \%$ CMC. All the groups of rats were observed twice daily for clinical signs and the time of onset, duration of these symptoms, mortality and morbidity till the completion of the experiment. Body weights of 
the rats in all groups were recorded once before the start of dosing, once weekly during the treatment period and finally on the day of sacrifice. The quantities of food and water intake were recorded daily and the data were expressed as 7 days cumulative value. At the end of the experiment (on 29th day), blood samples were collected from the rats after overnight fast (but with drinking water allowed) by retro-orbital bleeding into heparinized and non-heparinized tubes for hematological analysis and biochemical analysis, respectively

\section{Hematological parameters}

The heparinised blood was used for the analysis of hematological parameters such as hemoglobin, red blood cell count, white blood cell count, platelet count using fully automated hematology analyser (PE 6000).

\section{Biochemical parameters}

The serum was separated from non-heparinized blood and the serum biochemical parameters including total cholesterol, creatinine, alanine aminotransferase (ALT), aspartate aminotransferase (AST), alkaline phosphatase $(A L P)$, blood urea nitrogen (BUN), triglycerides, total cholesterol, albumin, bilirubin and total protein were analysed by using semi-automatic biochemical analyser (Star 21plus, India).

\section{Histopathology}

After blood collection on day 29, all the animals were euthanized for gross pathological examinations of all major internal organs. Organs such as liver, kidney, stomach, brain, heart and spleen were collected from all the animals for histopathology. The collected organs were weighed and preserved in $10 \%$ neutral buffered formalin, trimmed and a $5 \mu$ thickness of tissue sections was stained with hematoxylin and eosin for histopathological study.

\section{Statistical analysis}

Results are expressed as mean \pm SEM. One way ANOVA followed by Dunnett's test was used for data comparison and any $p<0.05$ was considered as statistically significant.

\section{RESULTS}

\section{Acute toxicity studies}

Oral administration of the EEOS at $2000 \mathrm{mg} / \mathrm{kg}$ and $5000 \mathrm{mg} / \mathrm{kg}$ did not produce any clinical signs of toxicity or deaths of the mice. As there were no mortality and clinical signs of toxicity in both the tested doses, LD $_{50}$ value of EEOS was found to be greater than $5000 \mathrm{mg} / \mathrm{kg}$.

\section{Sub acute toxicity studies}

There were no treatment related toxicity signs and mortality observed in both sexes of rats treated at $250 \mathrm{mg} / \mathrm{kg}, 500 \mathrm{mg} / \mathrm{kg}$ and $1000 \mathrm{mg} / \mathrm{kg}$ orally during the 4 weeks of treatment. No significant differences in body weight were observed between the initial and final body weight of the rats treated with EEOS and control rats (Figure 1). A similar absence of toxic effect was observed in the case of food consumption (Table 1). There were also no significant differences between control and EEOS treated groups in organ weight (Table 2). The hematological profile of treated and control group are summarized in Table 3. All hematological parameters such as total red blood cell count, total white blood cell count, platelet count, hemoglobin, hematocrit and differential leukocyte count were within normal range in both control and treated groups during the experimental period. Sub-acute administration of EEOS did not show any significant changes in biochemical parameters such as creatinine, urea, triglycerides, total cholesterol, total protein, albumin, aspartate aminotransferase (AST), alanine aminotransferase (ALT), alkaline phosphatase (ALP) and total bilirubin when compared to control groups (Table 4). There were no statistically significant differences in the hematological parameters and biochemical parameters measured between control and EEOS treated groups. Histopathological examinations of the brain, heart, liver, kidney, stomach and spleen of the control group mice and the mice that received high dose of EEOS revealed no abnormalities. The No-Observed Adverse Effect level (NOAEL) of the extract was estimated to be greater than $1000 \mathrm{mg} / \mathrm{kg} /$ day in rats.

\section{DISCUSSION}

Toxicological evaluation has revealed that in both acute and sub-acute toxicity test, EEOS did not produce any toxic effect in mice. In the acute toxicity study, no morbidity or mortality were observed in any mice, which survive throughout the 14 days of observation. $\operatorname{LD}_{50}$ value of the extract was found to be greater than $5000 \mathrm{mg} / \mathrm{kg}$. This finding, therefore, suggests that the extract at the limit dose tested is essentially non-toxic and safe after oral administration. 


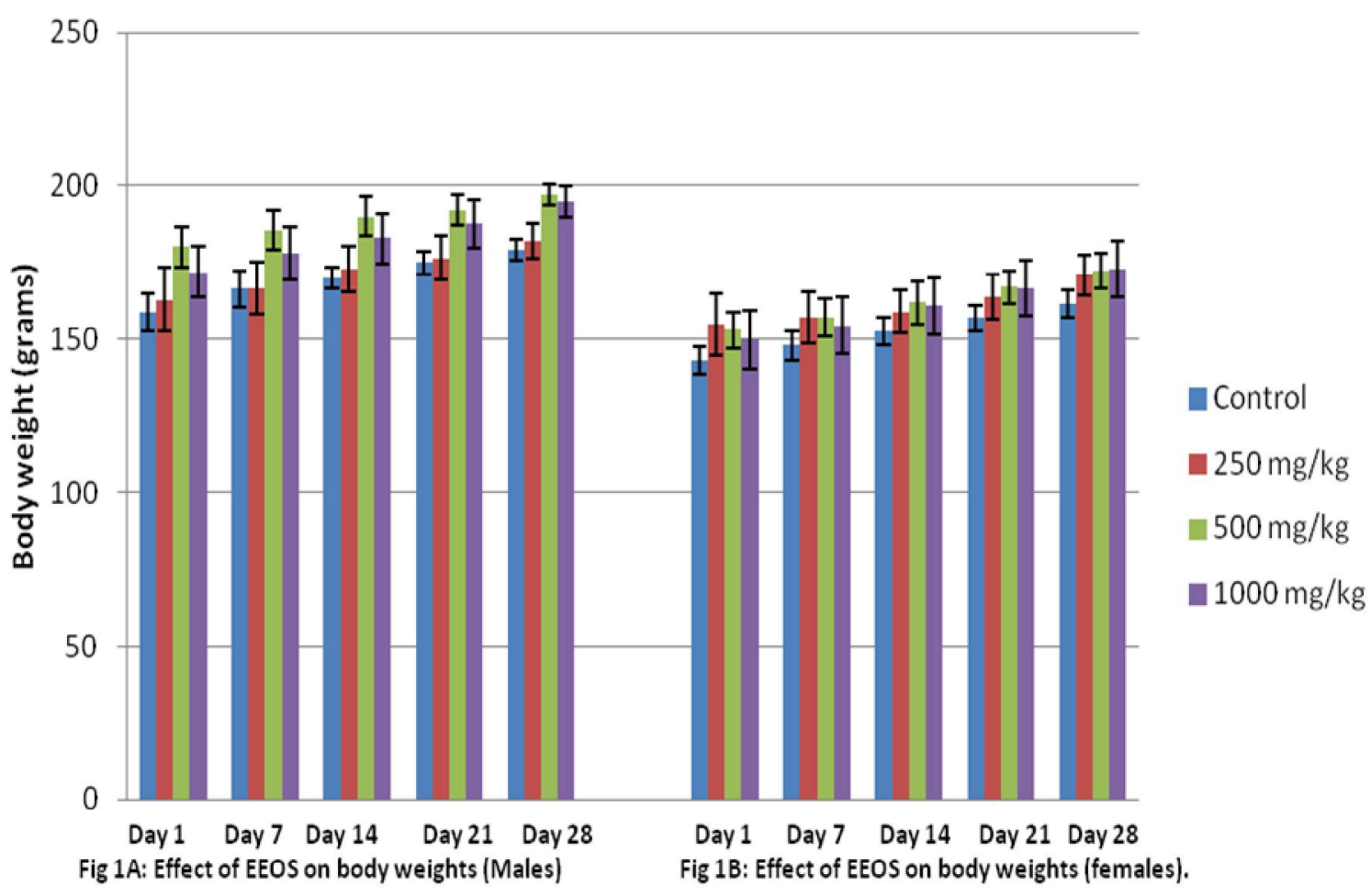

Figure 1: Effect of ethanol extract of Oncoba spinosa (EEOS) on body weights in experimental rats in sub-acute toxicity study

Table 1: Effect of ethanol extract of Oncoba spinosa (EEOS) on food intake in rats in sub-acute toxicity study

\begin{tabular}{lccccc}
\hline $\begin{array}{l}\text { Treatment } \\
\text { group }\end{array}$ & Sex & First week & Second week & Third week & Fourth week \\
\cline { 2 - 5 } & Males $(n=5)$ & $39.30 \pm 1.88$ & $36.55 \pm 1.71$ & $42.77 \pm 1.87$ & $40.62 \pm 1.99$ \\
\hline Control $(1 \%$ & Females $(n=5)$ & $32.50 \pm 1.92$ & $37.20 \pm 0.98$ & $45.88 \pm 1.46$ & $47.51 \pm 1.18$ \\
$250 \mathrm{mg} / \mathrm{kg}$ & Males $(\mathrm{n}=5)$ & $39.07 \pm 0.89$ & $36.84 \pm 1.18$ & $39.25 \pm 1.68$ & $42.04 \pm 1.69$ \\
& Females $(\mathrm{n}=5)$ & $38.95 \pm 1.50$ & $39.95 \pm 1.00$ & $44.94 \pm 1.76$ & $47.15 \pm 1.12$ \\
$500 \mathrm{mg} / \mathrm{kg}$ & Males $(\mathrm{n}=5)$ & $35.24 \pm 1.40$ & $40.17 \pm 2.75$ & $40.22 \pm 1.52$ & $42.62 \pm 1.60$ \\
& Females $(\mathrm{n}=5)$ & $33.30 \pm 1.30$ & $39.08 \pm 0.39$ & $42.70 \pm 1.47$ & $43.72 \pm 1.87$ \\
$1000 \mathrm{mg} / \mathrm{kg}$ & Males $(\mathrm{n}=5)$ & $37.87 \pm 1.47$ & $39.34 \pm 1.00$ & $40.20 \pm 1.31$ & $45.22 \pm 0.47$ \\
& Females $(\mathrm{n}=5)$ & $33.92 \pm 0.90$ & $39.92 \pm 1.35$ & $43.75 \pm 1.32$ & $45.67 \pm 1.44$ \\
\hline
\end{tabular}

Values are expressed as mean \pm SEM, $n=5$ females and 5 males

Table 2: Effect of Ethanolic extract of Oncoba spinosa (EEOS) on organ weights in rats in sub-acute toxicity study

\begin{tabular}{|c|c|c|c|c|c|c|c|c|}
\hline \multirow{3}{*}{$\begin{array}{l}\text { Organ } \\
\text { weight } \\
\text { (gms) }\end{array}$} & \multicolumn{8}{|c|}{ Treatment group } \\
\hline & \multicolumn{2}{|c|}{ Control (1\% CMC) } & \multicolumn{2}{|c|}{$250 \mathrm{mg} / \mathrm{kg}$} & \multicolumn{2}{|c|}{$500 \mathrm{mg} / \mathrm{kg}$} & \multicolumn{2}{|c|}{$1000 \mathrm{mg} / \mathrm{kg}$} \\
\hline & $\begin{array}{c}\text { Males } \\
(n=5)\end{array}$ & $\begin{array}{c}\text { Females } \\
(n=5)\end{array}$ & $\begin{array}{c}\text { Males } \\
(n=5)\end{array}$ & $\begin{array}{c}\text { Females } \\
(n=5)\end{array}$ & $\begin{array}{c}\text { Males } \\
(n=5)\end{array}$ & $\begin{array}{c}\text { Females } \\
(n=5)\end{array}$ & $\begin{array}{c}\text { Males } \\
(n=5)\end{array}$ & $\begin{array}{c}\text { Females } \\
(n=5)\end{array}$ \\
\hline Liver & $4.28 \pm 0.31$ & $4.19 \pm 0.26$ & $4.75 \pm 0.27$ & $4.68 \pm 0.31$ & $4.58 \pm 0.37$ & $4.28 \pm 0.24$ & $5.07 \pm 0.49$ & $3.83 \pm 0.25$ \\
\hline Brain & $1.45 \pm 0.03$ & $1.47 \pm 0.05$ & $1.54 \pm 0.11$ & $1.65 \pm 0.06$ & $1.51 \pm 0.09$ & $1.59 \pm 0.11$ & $1.72 \pm 0.06$ & $1.40 \pm 0.07$ \\
\hline Spleen & $0.47 \pm 0.05$ & $0.45 \pm 0.02$ & $0.49 \pm 0.05$ & $0.47 \pm 0.01$ & $0.46 \pm 0.04$ & $0.42 \pm 0.04$ & $0.42 \pm 0.04$ & $0.41 \pm 0.02$ \\
\hline Kidney & $1.01 \pm 0.06$ & $1.05 \pm 0.07$ & $1.01 \pm 0.05$ & $1.07 \pm 0.04$ & $1.19 \pm 0.09$ & $1.08 \pm 0.06$ & $1.07 \pm 0.07$ & $1.02 \pm 0.03$ \\
\hline Heart & $0.71 \pm 0.03$ & $0.69 \pm 0.02$ & $0.61 \pm 0.02$ & $0.65 \pm 0.01$ & $0.68 \pm 0.02$ & $0.70 \pm 0.02$ & $0.67 \pm 0.05$ & $0.71 \pm 0.04$ \\
\hline Stomach & $2.57 \pm 0.18$ & $2.69 \pm 0.17$ & $3.22 \pm 0.09$ & $3.25 \pm 0.14$ & $2.87 \pm 0.21$ & $3.11 \pm 0.15$ & $2.80 \pm 0.18$ & $3.10 \pm 0.17$ \\
\hline
\end{tabular}

Values are expressed as mean $\pm S E M, n=5$ females and 5 males 
Table 3: Effect of Ethanolic extract of Oncoba spinosa (EEOS) on hematological parameters in sub-acute toxicity study

\begin{tabular}{lccccc}
\hline Hematological & Sex & \multicolumn{3}{c}{ Treatment group } \\
\cline { 3 - 6 } Parameter & & Control & $\mathbf{2 5 0} \mathbf{~ m g} / \mathbf{k g}$ & $\mathbf{5 0 0} \mathbf{~ m g} / \mathbf{k g}$ & $\mathbf{1 0 0 0} \mathbf{~ m g} / \mathbf{k g}$ \\
\hline Hemoglobin $(\mathrm{g} / \mathrm{dl})$ & Males $(\mathrm{n}=5)$ & $13.32 \pm 0.73$ & $14.62 \pm 0.34$ & $14.36 \pm 0.66$ & $14.58 \pm 0.83$ \\
& Females $(\mathrm{n}=5)$ & $14.52 \pm 0.71$ & $15.34 \pm 0.41$ & $15.74 \pm 0.50$ & $16.38 \pm 0.40$ \\
RBC count $\left(\mathrm{x} 10^{6} / \mu \mathrm{l}\right)$ & Males $(\mathrm{n}=5)$ & $4.76 \pm 0.33$ & $4.96 \pm 0.31$ & $4.80 \pm 0.43$ & $5.22 \pm 0.34$ \\
& Females $(\mathrm{n}=5)$ & $5.46 \pm 0.30$ & $6.02 \pm 0.24$ & $6.54 \pm 0.20$ & $6.40 \pm 0.32$ \\
WBC count $\left(\mathrm{x} 10^{3} / \mu \mathrm{l}\right)$ & Males $(\mathrm{n}=5)$ & $9.10 \pm 0.49$ & $8.52 \pm 0.61$ & $8.68 \pm 0.37$ & $9.78 \pm 0.69$ \\
& Females $(\mathrm{n}=5)$ & $10.58 \pm 0.40$ & $10.18 \pm 0.50$ & $9.29 \pm 0.52$ & $10.72 \pm 0.36$ \\
Platelet count & Males $(\mathrm{n}=5)$ & $827.51 \pm 38.04$ & $866.03 \pm 40.54$ & $886.38 \pm 33.22$ & $903.89 \pm 31.38$ \\
(x10 $/ \mu \mathrm{l})$ & Females $(\mathrm{n}=5)$ & $845.51 \pm 42.00$ & $852.03 \pm 39.42$ & $860.38 \pm 38.97$ & $874.14 \pm 18.75$ \\
Hematocrit $(\%)$ & Males $(\mathrm{n}=5)$ & $44.32 \pm 1.67$ & $46.46 \pm 2.22$ & $45.76 \pm 1.25$ & $49.74 \pm 1.83$ \\
& Females $(\mathrm{n}=5)$ & $40.46 \pm 0.84$ & $41.24 \pm 1.99$ & $40.56 \pm 0.99$ & $42.14 \pm 1.83$ \\
Neutrophils $(\%)$ & Males $(\mathrm{n}=5)$ & $48.84 \pm 2.43$ & $51.50 \pm 2.52$ & $54.74 \pm 1.89$ & $53.48 \pm 1.80$ \\
& Females $(\mathrm{n}=5)$ & $43.84 \pm 1.52$ & $44.80 \pm 0.53$ & $46.76 \pm 0.80$ & $45.36 \pm 1.14$ \\
Lymphocytes $(\%)$ & Males & $34.92 \pm 1.41$ & $29.62 \pm 1.62$ & $34.70 \pm 1.80$ & $33.54 \pm 2.33$ \\
& Females $(\mathrm{n}=5)$ & $35.66 \pm 1.66$ & $31.04 \pm 1.02$ & $31.92 \pm 1.43$ & $33.98 \pm 2.09$ \\
Eosinophils $(\%)$ & Males $(\mathrm{n}=5)$ & $3.26 \pm 0.48$ & $3.78 \pm 0.47$ & $4.06 \pm 0.37$ & $4.00 \pm 0.34$ \\
& Females $(\mathrm{n}=5)$ & $3.50 \pm 0.31$ & $3.76 \pm 0.35$ & $3.70 \pm 0.36$ & $4.40 \pm 0.37$ \\
Monocytes $(\%)$ & Males $(\mathrm{n}=5)$ & $5.66 \pm 0.39$ & $5.70 \pm 0.57$ & $5.82 \pm 0.59$ & $5.24 \pm 0.19$ \\
& Females $(\mathrm{n}=5)$ & $4.16 \pm 0.26$ & $3.96 \pm 0.39$ & $3.74 \pm 0.67$ & $4.40 \pm 0.27$ \\
Basophils $(\%)$ & Males $(\mathrm{n}=5)$ & $0.94 \pm 0.19$ & $1.30 \pm 0.10$ & $1.0 \pm 0.22$ & $1.06 \pm 0.24$ \\
& Females $(\mathrm{n}=5)$ & $0.84 \pm 0.17$ & $0.96 \pm 0.24$ & $0.50 \pm 0.27$ & $0.66 \pm 0.20$ \\
\hline
\end{tabular}

Values are expressed as mean $\pm S E M, n=5$ females +5 males

Table 4: Effect of ethanol extract of Oncoba spinosa (EEOS) on biochemical parameters-in sub-acute toxicity study

\begin{tabular}{|c|c|c|c|c|c|}
\hline \multirow{2}{*}{$\begin{array}{l}\text { Biochemical } \\
\text { Parameter }\end{array}$} & \multirow[t]{2}{*}{ Sex } & \multicolumn{4}{|c|}{ Treatment group } \\
\hline & & Control & $250 \mathrm{mg} / \mathrm{kg}$ & $500 \mathrm{mg} / \mathrm{kg}$ & $1000 \mathrm{mg} / \mathrm{kg}$ \\
\hline \multirow[t]{2}{*}{ Creatinine (mg/dl) } & Males $(n=5)$ & $1.40 \pm 0.19$ & $1.14 \pm 0.27$ & $1.26 \pm 0.19$ & $1.02 \pm 0.24$ \\
\hline & Females $(n=5)$ & $1.14 \pm 0.19$ & $1.32 \pm 0.29$ & $1.00 \pm 0.20$ & $1.24 \pm 0.28$ \\
\hline \multirow[t]{2}{*}{ Glucose (mg/dl) } & Males $(n=5)$ & $72.18 \pm 3.34$ & $81.80 \pm 3.24$ & $75.90 \pm 2.44$ & $84.38 \pm 5.37$ \\
\hline & Females $(n=5)$ & $91.40 \pm 3.68$ & $89.58 \pm 3.27$ & $90.62 \pm 2.73$ & $101.98 \pm 1.34$ \\
\hline \multirow{4}{*}{$\begin{array}{l}\text { Total protein } \\
\text { (g/dl) } \\
\text { ALP (U/L) }\end{array}$} & Males $(n=5)$ & $7.18 \pm 0.34$ & $6.68 \pm 0.27$ & $6.84 \pm 0.31$ & $7.12 \pm 0.36$ \\
\hline & Females $(n=5)$ & $6.50 \pm 0.36$ & $6.94 \pm 0.35$ & $6.76 \pm 0.24$ & $7.24 \pm 0.37$ \\
\hline & Males $(n=5)$ & $71.18 \pm 5.49$ & $82.02 \pm 4.39$ & $78.62 \pm 4.62$ & $84.62 \pm 6.92$ \\
\hline & Females $(n=5)$ & $81.10 \pm 5.33$ & $87.24 \pm 3.65$ & $80.28 \pm 4.57$ & $95.84 \pm 2.35$ \\
\hline \multirow[t]{2}{*}{ AST (U/L) } & Males $(n=5)$ & $51.44 \pm 2.63$ & $55.30 \pm 2.97$ & $55.44 \pm 1.82$ & $53.76 \pm 3.53$ \\
\hline & Females $(n=5)$ & $48.94 \pm 2.99$ & $53.90 \pm 3.13$ & $54.02 \pm 1.68$ & $49.76 \pm 2.72$ \\
\hline \multirow[t]{2}{*}{ ALT (U/L) } & Males $(n=5)$ & $44.88 \pm 2.86$ & $49.52 \pm 1.39$ & $44.26 \pm 2.57$ & $45.78 \pm 1.46$ \\
\hline & Females $(n=5)$ & $40.24 \pm 0.60$ & $44.62 \pm 1.55$ & $43.94 \pm 2.56$ & $46.40 \pm 2.34$ \\
\hline \multirow[t]{2}{*}{ BUN (mg/dl) } & Males $(n=5)$ & $28.86 \pm 2.21$ & $35.90 \pm 1.88$ & $35.86 \pm 2.65$ & $33.98 \pm 2.03$ \\
\hline & Females $(n=5)$ & $27.24 \pm 1.96$ & $32.72 \pm 1.03$ & $31.80 \pm 0.74$ & $31.98 \pm 0.62$ \\
\hline \multirow{4}{*}{$\begin{array}{l}\text { Triglycerides } \\
\text { (mg/dl) } \\
\text { Total cholesterol } \\
(\mathrm{mg} / \mathrm{dl})\end{array}$} & Males $(n=5)$ & $66.18 \pm 3.13$ & $55.30 \pm 2.13$ & $57.68 \pm 4.19$ & $67.50 \pm 3.69$ \\
\hline & Females $(n=5)$ & $65.66 \pm 2.23$ & $59.30 \pm 3.91$ & $60.08 \pm 2.42$ & $68.46 \pm 2.07$ \\
\hline & Males $(n=5)$ & $89.46 \pm 6.39$ & $78.04 \pm 3.56$ & $101.68 \pm 1.05$ & $98.40 \pm 2.42$ \\
\hline & Females $(n=5)$ & $80.54 \pm 3.53$ & $80.62 \pm 2.78$ & $90.90 \pm 2.91$ & $90.76 \pm 4.02$ \\
\hline \multirow[t]{2}{*}{ Albumin (g/dl) } & Males $(n=5)$ & $3.92 \pm 0.28$ & $4.70 \pm 0.25$ & $4.64 \pm 0.33$ & $4.70 \pm 0.18$ \\
\hline & Females $(n=5)$ & $4.36 \pm 0.38$ & $4.24 \pm 0.27$ & $4.42 \pm 0.24$ & $4.40 \pm 0.22$ \\
\hline \multirow[t]{2}{*}{ T.Bilirubin (mg/dl) } & Males $(n=5)$ & $0.84 \pm 0.18$ & $1.20 \pm 0.13$ & $0.72 \pm 0.24$ & $1.26 \pm 0.22$ \\
\hline & Females $(n=5)$ & $0.66 \pm 0.18$ & $0.76 \pm 0.17$ & $0.50 \pm 0.16$ & $0.78 \pm 0.25$ \\
\hline
\end{tabular}

Values are expressed as mean \pm SEM, $n=5$ females +5 males

The sub-acute dose was selected based on the rats $L D_{50}$ value which kept rats alive, i.e. $1 / 5$, $1 / 10$ and $1 / 20$ of $L D_{50}$ value of $5000 \mathrm{mg} / \mathrm{kg}$. In repeated dose 28-day oral toxicity study, there were no deaths and treatment-related signs were observed in all the groups of animals.

Similarly, no significant differences in food and water intake, weight gain, biochemical and haematological parameters were observed between control and treated groups during this period. Histopathological examination of selected vital organs (heart, brain, liver, kidney, spleen and stomach) from both treated and control animals showed normal architecture, suggesting no microscopic changes and morphological disturbances were caused due to oral administration of EEOS at highest dose level. 
Although acute toxicity helps to determine the toxicity nature of substances, it is important to assess sub-acute toxicity profile because it helps to evaluate the morphological and physiological changes in organs. It is important to determine the food intake and water consumption during the investigation of safety of a product with medicinal purpose, as proper intake of supplements is important to the physiological status of the animal and to the achievement of best possible response to the compounds under investigation $[11,12]$.

In this study, the food intake and water consumption were not affected by the administration of extract and it did not promote any appetite suppression and had no harmful effects. Thus, this indicates there was no interruption in the metabolism of carbohydrate, protein and fat [13]. After exposure to few possible toxic substances, there will be changes in body weight gain and internal organ weights which would reflect toxicity [14]. The body weight changes are markers of adverse effects of drugs and chemicals and if the body weight loss observed is more than $10 \%$ of initial body weight, it will be considered as statistically significant $[15,16]$. Organ weight also is an important indicator of physiological and pathological status of animals. The relative organ weight is fundamental to confirm whether the organ weight was exposed to the injury or not. The heart, liver, kidney, spleen and lungs are the primary organs affected by metabolic reaction caused by toxicant [17]. There were no significant differences in body weight gain between control and treated groups. In the present study, organ weights in all the treated groups of both sexes were not significantly different from those of control groups. Hence it can be concluded that EEOS is almost non-toxic.

Hematological parameters are some of the most sensitive to evaluate the toxicity of medicines in humans and animals, and a blood profile normally gives important information on the reaction of body to damage or stress $[18,19]$. There were no statistically significant, dosedependent adverse effects on any of the hematological parameters in both male and female rats after 4 weeks of EEOS treatment. In addition, there were no significant alterations in biochemical parameters in all the groups treated with a 4-week repeated dose of EEOS. Elevated bilirubin values are an indication of altered liver functions and a small elevation is an important indicator of liver damage in laboratory animals or could be a sign of biliary duct obstruction. Liver is the primary site for the synthesis of plasma proteins especially albumin and alterations in the total plasma proteins may indicate liver dysfunction [20].

In this study, daily administration of EEOS for 28 days did not produce any significant changes in total protein and albumin of the treated rats from all the doses used compared to the control group. AST, ALT and ALP are the important serum biomarker enzymes usually measured to evaluate any toxic effects of the medicines on liver [21]. In the present study, no significant differences in the levels of AST, ALT and ALP in male and female rats were observed. Creatinine and BUN are known to be important markers of renal dysfunction [18]. Similarly, no significant differences in creatinine and BUN values were found in treated rats compared with the control group. These results suggest that EEOS does not have a toxic effect on the liver and kidneys. Histological analysis was done to further confirm the alteration in cell structure of the organs. The histopathological examination is the golden standard for evaluating the treatment related pathological changes in tissues and organs [22]. No abnormal findings were observed on histopathological examination of all the organs examined. Since no signs of toxicity were observed in all the tested groups with respect to hematology, biochemistry, organ weights, body weights and histopathological examination, it can be concluded that EEOS is non-toxic. Based on the results, the No Observed Adverse Effect Level (NOAEL) was found to be greater than $1000 \mathrm{mg} / \mathrm{kg} /$ day.

\section{CONCLUSION}

The ethanol extract of the root of $O$. spinosa is relatively safe, as they did not cause death or any abnormal changes in both acute and subchronic toxicity studies. Further studies will be required to investigate the potential medical significance of the plant.

\section{REFERENCES}

1. Raskin I, Ribnicky DM, Komarnytsky S, llic N, Poulev A, Borisjuk N, Brinker A, Moreno DA, Ripoll C, Yakoby $N$, et al. Plants and human health in the twenty-first century. Trends Biotech 2002; 20(12):522-531.

2. Kuiate JR, Bessiere JM, Amvam ZP, Kuate SP. Chemical composition and antidermatophytic properties of volatile fractions of hexanic extract from leaves of Cupressus lusitanica Mill. from Cameroon. J Ethnopharmacol 2006; 103:160-165. 
3. Joshi CS, Priya ES, Venkataraman S. Acute and subacute toxicity studies on the polyherbal antidiabetic formulation Diakyur in experimental animal models. Journal of Health Science 2007; 52 . 245-249.

4. Lahlou S, Israili ZH, Lyoussi B. Acute and chronic toxicity of a lyophilised aqueous extract of Tanacetum vulgare leaves in rodents. J Ethnopharmacol 2008; 117: 221-227.

5. Saad B, Azaizeh H, Abu-Hijleh G, Said O. Safety of traditional arab herbal medicine. Evid Based Complement Alternat Med 2006; 3:433-439.

6. Schoepfer AM, Engel A, Fattinger $K$, Marbet UA, Criblez $D$, Reichen J, Zimmermann A, Oneta CM. Herbal does not mean innocuous: Ten cases of severe hepatotoxicity associated with dietary supplements from Herbalife products. J Hepatol 2007; 47:521-526

7. Burkil HM. The useful Plants of West Tropical Africa 2nd edn. Families E-I. Royal Botanic Garden, Kew, 1984; 2: 161-162

8. Burkil HM. The useful Plants of West Tropical Africa 2nd edn. Families E-I. Royal Botanic Garden,Kew, 1994; 2: $160-162$

9. OECD guidelines for testing of chemicals, Test No. 425, Acute toxic class method. Organization for Economic Cooperation and Development, 2008.

10. Guidelines for the Testing of Chemicals/Draft Updated Test Guideline 407: Repeated Dose 28-Day Oral Toxicity Study in Rodents. Organization for Economic Cooperation and Development, 2008.

11. Steven KR, Mylecrdfaine L. Issues in Chronic Toxicology. In: Hayes AW editor. Principles and Methods of Toxicology, 3rd Ed. New York: Ravan Press; 1994. p. 673.

12. Iversen PO, Nicolaysen, G. Water for life. J Norw Med Assoc 2003; 123: 3402-3405.

13. Klaassen CD. Principles of Toxicology. In Casarett and Doull's Toxicology: The Basic Science of Poisons, 5th ed. New York: McGraw-Hill; 2001. p. 13.
14. Carol SA. Acute, Subchronic and Chronic Toxicology. In: Michael JD, Mannfred AH editors. CRC Handbook of Toxicology, CRC Press Inc.: Boca Raton; 1995. $p$. 51-104.

15. Raza M, Al-Shabanah OA, El-Hadiyah TM, Al-Majed AA. Effect of prolonged vigabatrin treatment on hematological and biochemical parameters in plasma, liver and kidney of Swiss albino mice. Sci Pharm 2002; 70: 135-145.

16. Teo SD, Stirling S, Thomas A, Kiorpes A, Vikram K. A 90day oral gavage toxicity study of D-methylphenidate and $D, L$ methylphenidate in Sprague-dawley rats. Toxicology 2002; 179: 183-196.

17. Dybing E, Doe J, Groten J, Kleiner J, O'Brien, J. Hazard characterization of chemicals in food and diet: dose response, mechanism and extrapolation issues. Food Chem. Toxicol 2002; 42: 237-282.

18. Mukinda JT, Eagles PF. Acute and sub-chronic oral toxicity profiles of the aqueous extract of Polygala fruticosa in female mice and rats. J Ethnopharmacol 2010; 128: 236-240.

19. Liju VB, Jeena K, Kuttan R. Acute and subchronic toxicity as well as mutagenic evaluation of essential oil from turmeric (Curcuma longa L.). Food Chem Toxicol 2013; 53: 52-61.

20. Saravanan N, Nalini N. Hemidesmus indicus protects against ethanol-induced liver toxicity. Cell Mol Biol Lett 2008; 13: 20-37.

21. Ramaiah SK. Preclinical safety assessment: Current gaps, challenges, and approaches in identifying translatable biomarkers of drug-induced liver injury. Clin Lab Med 2011; 31: 161-172.

22. OECD. OECD Guideline for Testing of Chemicals. Repeated Dose 28-Day Oral Toxicity Study in Rodents; Organisation for Economic Co-operation and Development: Paris, France, 1995. 